\title{
Inheritance of mating-system modifier genes in Eichhornia paniculata (Pontederiaceae)
}

\author{
CHARLES B. FENSTER* \& SPENCER C. H. BARRETT† \\ Department of Botany, University of Maryland, College Park, MD 20742-5815, U.S.A. and +Department of Botany, \\ University of Toronto, Toronto, Ontario, Canada M5S $3 B 2$
}

\begin{abstract}
The evolutionary breakdown of tristyly to predominant self-fertilization in Eichhornia paniculata (Pontederiaceae) is associated with the spread and fixation of floral variants of the mid-styled morph (M) with modified short-level stamens. Reduced stigma-anther separation in the variants results in a high degree of self-fertilization. To investigate if the genetic basis of mating-system modification differs among floral variants from different parts of the geographical range of the species we performed controlled crosses on genotypes from six populations from N.E. Brazil and Jamaica. Measurements of floral traits in self and $F_{1}$ crosses grown under uniform glasshouse conditions demonstrated that the gene(s) modifying stamen position in the $\mathrm{M}$ morph are largely recessive, have no apparent phenotypic effects on other floral characters and are only expressed in the $M$ morph. Crosses between modified genotypes from northern and southern parts of N.E. Brazil resulted in $F_{1}$ progeny with unmodified flowers, indicating that different recessive genes are responsible for stamen modification in the two regions. Crosses between modified genotypes from Jamaica and the two regions of N.E. Brazil indicated a more complex basis for stamen modification in Jamaica, and confirmed that the genetic basis of selfing differed between the two regions of Brazil. Our results provide evidence that the evolution of self-fertilization in $E$. paniculata has occurred by different genetic pathways. In addition, the data suggest that the sequence of events commences with the fixation of recessive alleles affecting only filament length, followed by evolution at modifier loci responsible for larger phenotypic changes to floral architecture.
\end{abstract}

Keywords: Eichhornia paniculata, mating system, selfing, tristyly.

\section{Introduction}

Mating patterns in plant populations are governed by complex interactions between floral traits and ecological factors affecting pollen dispersal. In self-compatible species the relative positions of female and male reproductive organs within a flower can have important consequences for levels of self- and cross-fertilization (e.g. Ennos, 1981; Barrett \& Shore, 1987). Theoretical models of mating-system evolution generally indicate that the genetic architecture of floral traits influencing mating patterns will have an important influence on the dynamics of mating system change (Fisher, 1941; Lande \& Schemske, 1985; Campbell, 1986; Charlesworth \& Charlesworth, 1990; Holsinger, 1992; Latta \& Ritland, 1993). In these models, workers have usually investigated the effects of a single modifier locus on the evolution of the selfing rate. It remains unclear, however, how common major gene control of floral traits with significant effects on the mating system

*Correspondence. in self-compatible species may be, primarily because relatively few studies have investigated the genetic basis of variation in style and stamen positioning within wild plant populations.

Most studies that have reported genetic data on floral traits have revealed complex patterns with quantitative inheritance and often significant environmental effects (Breese, 1959; Moore \& Lewis, 1965; Schoen, 1982; Macnair \& Cumbes, 1989; Shore \& Barrett, 1990; Holtsford \& Ellstrand, 1992; Fenster \& Ritland, 1994). However, a few studies have shown major gene control of floral traits influencing mating patterns (Rick, 1947; Vasek, 1968; Jain et al., 1979; Marshall \& Abbott, 1982; Brown \& Clegg, 1984) and, in some cases, this has enabled considerable progress to be made in understanding the factors influencing mating-system evolution (e.g. of Senecio vulgaris, Ross \& Abbott, 1987; Holsinger, 1992, and of Ipomoea purpurea, Clegg \& Epperson, 1988).

Perhaps the most well-known examples of the genetic control of mating-system change in flowering 
plants involve the breakdown of heterostylous breeding systems to predominant self-fertilization via homostyle formation (Mather, 1950; Ernst, 1955; Dowrick, 1956; Baker, 1966; Charlesworth \& Charlesworth, 1979; Shore \& Barrett, 1985). The origin of selfing homostylous phenotypes, through recombination in the supergene that governs the polymorphism, represents one of the few cases in plants of a quantum change in the mating system known to be brought about by a simple genetic change (Baker, 1959; Barrett, 1989).

In tristylous plants, the evolution of self-fertilization by homostyle formation appears to involve genetic mechanisms distinct from those reported in most distylous groups (Barrett, 1979, 1988, 1992; Charlesworth, 1979). For example, in the self-compatible, annual diploid Eichhornia paniculata (Spreng.) SolmsLaubach (Pontederiaceae) selfing phenotypes arise mainly through alteration to the position of short-level stamens in the mid-styled morph. This modification results in dramatic increases in the selfing rate of populations (Glover \& Barrett, 1986; Barrett \& Husband, 1990). The most common altered phenotype observed in nature has a single 'short-level' stamen elongated to the same position as the mid-level stigma. Although less frequent, plants with two or three stamens at the mid-level position also occur (Barrett, 1985; Richards \& Barrett, 1992). It seems unlikely that these various floral modifications result from recombination at the two diallelic gene loci $(S$ and $M)$ that govern the inheritance of tristyly (Lewis \& Jones, 1992). Rather, the stamen modifications that promote selfing are more likely to result from effects of modifier genes non-allelic to the genes at the tristyly loci. To investigate this problem further we initiated a study of the genetic basis of floral modifications governing the mating system of $E$. paniculata by the use of controlled crosses and the measurements of floral traits in glasshouse-grown progeny.

Three main issues were addressed in our study. (1) We were interested in determining whether the gene(s) modifying the short-level stamen position in the mid-styled morph of E. paniculata had any observable morphological effects on other floral traits. (2) We wanted to investigate the role of dominance in the expression of genes responsible for reproductive organ positioning. (3) Since predominant self-fertilization appears to have originated independently in different parts of the range of E. paniculata (Husband \& Barrett, 1993), crosses among genotypes exhibiting the selfing phenotype from six geographically separated populations were made to determine whether different genes were involved in altering stamen position in the midstyled morph.

\section{Materials and methods}

To investigate the genetic basis of short-level stamen modification in the mid-styled morph of E. paniculata (hereafter M modification), we used eight modified genotypes from six populations from different parts of the geographical range of the species. The populations from which genotypes were chosen exhibited different stages in the breakdown of tristyly, representing trimorphic, dimorphic and monomorphic populations (Table 1). Five genotypes were sampled from four populations (B2, B3, B10, B58) from the southern range of the species in N.E. Brazil, two genotypes from a single population (B46) in the northern part of the Brazilian range and one genotype $(\mathrm{J} 11)$ was sampled from a single population from Jamaica (see Fig. 2 in Barrett et al., 1989 for a distribution map of E. paniculata). In addition, one unmodified mid-styled genotype (from population B46) was also used in crosses with modified plants. The phenotypes of modified and unmodified mid-styled plants are illustrated in Fig. 1, and Table 1 provides information on the source of populations and details of the representation of floral morphs within each population. All plants were grown from open-pollinated seed families and maintained under heated $\left(25-30^{\circ} \mathrm{C}\right)$ glasshouse conditions in 10 $\mathrm{cm}$ pots submerged in individual water-filled plastic containers. All genotypes are designated by a population code, plant number and whether the plants are modified $\left(\mathbf{M}^{\prime}\right)$ or unmodified mid-styled plants $(\mathbf{M})$.

Preliminary crosses between modified and unmodified genotypes of the $\mathrm{M}$ morph of $E$. paniculata indicated that stamen modifications were under recessive gene control (S. C. H. Barrett, unpublished data). To confirm this result six modified genotypes from each of

Table 1 Populations of Eichhornia paniculata from which genotypes used in the crossing programme originated; the population code and location (B, N.E. Brazil and J, Jamaica), and morph composition ( $\mathrm{T}, \mathrm{D}, \mathrm{M}$, trimorphic, dimorphic or monomorphic for style morph; L, M, S, long-, mid- or shortstyled morph) of each population are given

Morph representation

\begin{tabular}{llcccc}
\cline { 4 - 6 } Code & \multicolumn{1}{c}{ Location } & & L & M & S \\
\hline B2 & Bom Conselho, Pernambuco & T & 0.61 & 0.25 & 0.14 \\
B3 & Jupi, Pernambuco & D & 0.29 & 0.71 & - \\
B10 & Arapiraca, Alagoas & D & 0.11 & 0.89 & - \\
B46 & Quixada, Ceara & T & 0.64 & 0.27 & 0.09 \\
B58 & Bom Jardin, Pernambuco & T & 0.36 & 0.42 & 0.22 \\
J11 & Angels, St. Catherine & M & - & 1.00 & - \\
\hline
\end{tabular}



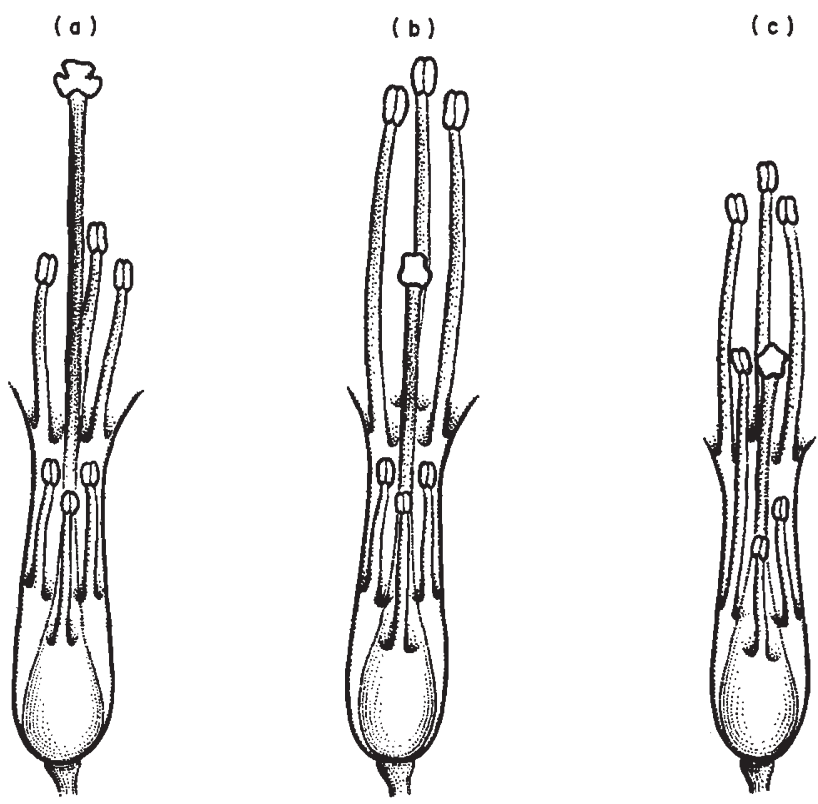

Fig. 1 Stamen and style positions for unmodified phenotypes of the (a) long- and (b) mid-styled morphs of Eichhornia paniculata and (c) a self-pollinating variant of the mid-styled morph. Note the elongation of a single short-level stamen in the self-pollinating variant so that it is adjacent to the mid-level stigma. This modification results in automatic self-pollination of the flower. The long- and mid-styled morphs are from a tristylous population from N.E. Brazil. The self-pollinating variant is from Jamaica. Flower size in Jamaican populations is generally smaller than in populations from Brazil (see Barrett, 1985).

six populations were reciprocally crossed to an unmodified genotype of the $\mathrm{M}$ morph from population B46 (B46-1M), and compared to selfed progeny of the unmodified genotype (totalling seven full-sib families). The degree of dominance in crosses among genotypes was measured in terms of $h$, where $h=\left(\mathrm{F}_{1}-\mathrm{P}_{1}\right) /$ $\left(\mathrm{P}_{1}-\mathrm{P}_{2}\right)$ (after Wright, 1968). A value of $h=0.5$ corresponds to the absence of dominance in the $F_{1}$, while values of 0 or 1 correspond to $F_{1}$ progeny resembling either parent. Departure from midparent values $(h=0.5)$ were tested using $t$-tests.

To investigate whether the genetic basis of stamen modification differed among populations, six modified $M$ genotypes from the six different populations were crossed reciprocally in all pairwise combinations as well as selfed, giving a total of 21 full-sib families. In addition, in two populations (B46 and B48), crosses were made between modified genotypes to determine if different loci responsible for stamen modification exist within populations. Including the selfed pollinations, these crosses added four full-sib families to the experiment. In all crosses involving modified genotypes, elongated stamens were emasculated before hand cross-pollination to prevent the automatic self-pollination of flowers.

In total, 1414 progeny representing 32 full-sib families were obtained from the above crosses and were grown to flowering in a single glasshouse during the summer of 1989. An attempt was made to sample between $40-80$ progeny per family, and a single flower was measured on each plant. Data were pooled for all reciprocal crosses since no maternal effects were observed among the crosses. All flowers were sampled from the first or second inflorescence produced by each plant, and the flower used for measurement was chosen to be as representative of the genotype being measured as possible. In cases where some intraplant variation in stamen position was evident (see Seburn et al., 1990; Barrett \& Harder, 1992), modified flowers were chosen for measurement so long as this condition predominated on the inflorescence.

To determine associations among floral characters, the following traits were measured on each flower in selected families segregating for filament elongation: (1) stamen height from the base of the ovary for all six stamens, (2) free filament length for all six stamens, (3) point of attachment of free filament to perianth tube measured from the base of the ovary for all six stamens (1-2), (4) pistil length from the base of the ovary, (5) style length, (6) ovary length (4-5), (7) stigma-anther separation (4-1), (8) corolla width, and (9) nectar guide length. For a diagram illustrating these traits in the $M$ morph of $E$. paniculata and discussion of their measurement, see Seburn et al. (1990). Since some of the genotypes chosen for the study were heterozygous $(\mathrm{Mm})$ at the $M$ locus governing the long-versus midstyled phenotype, some families contained progeny that were long-styled. Floral measurements were also undertaken on these plants.

Our method of determining whether the modification of the short-level stamens has a similar or different genetic basis across the range of $E$. paniculata was to examine the frequency of the modified mid-styled phenotype in $F_{1}$ progeny of crosses between modified genotypes. Because preliminary evidence demonstrated that the modified condition is recessive to the unmodified state, we hypothesized that if the genetic basis for modification varied within or among populations then complementary gene action among recessives would give recovery of wild-type progeny. Different genetic control of short-level modification was determined by recovery of $F_{1}$ offspring that differed significantly from either modified parent and which resembled the unmodified phenotype. Departure from the modified mid-styled phenotype in $F_{1}$ crosses among modified mid-styled plants was determined by using Scheffé contrasts following one-way ANOVA. 


\section{Results}

\section{Correlations of stamen characters with other floral traits}

Decreased stigma-anther separation in modified genotypes is determined by increased filament length and higher placement of the free filament on the perianth tube, not through changes in pistil length [Pearson correlation of stigma-anther separation with filament length, height of attachment on perianth, style length and ovary length $=-0.897, \quad P<0.001 ; \quad-0.527$, $P<0.001 ;-0.068, P<0.05 ; 0.045$, not significant, respectively, and see Fig. 1, and Table 2 (top)]. Filament characteristics of the modified stamen were uncorrelated with variation in upper level stamens. Measurements of perianth width and nectar guide length among self progeny of genotypes which appear to be segregating for filament length (B46-1 $\mathrm{M}^{\prime}, \mathrm{B} 58$ $1 \mathrm{M}^{\prime}, \mathrm{B} 58-2 \mathrm{M}^{\prime}$ and $\mathrm{B} 10-1 \mathrm{M}^{\prime}, n=96$ progeny), revealed little correlation (none $>0.25$ ) with either of the two filament characters for both short- and long-level stamens. These patterns were also observed in analyses including progeny from all crosses.

Modifications of short-level stamens in E. paniculata are restricted to the $\mathrm{M}$ morph. Measurements of filament length of short-level stamens in $\mathrm{L}$ and $\mathrm{M}$ morphs segregating from self-pollinations of five heterozygous modified $\mathrm{M}$ plants indicated clear differences between the two floral phenotypes (Table 3). While plants of the $\mathrm{M}$ morph uniformly displayed modified stamens, the developmentally homologous stamens of the L morph were exclusively unmodified. The difference in stamen modification in the two morphs resulted in contrasting patterns of stigma-anther separation (Table 3).

Table 2 Mean filament position and mean filament length of modifiable stamens in Eichhornia paniculata; means followed by different letters are significantly different $(P<0.05$, Scheffé's contrasts $)$; S.E.s are in parentheses

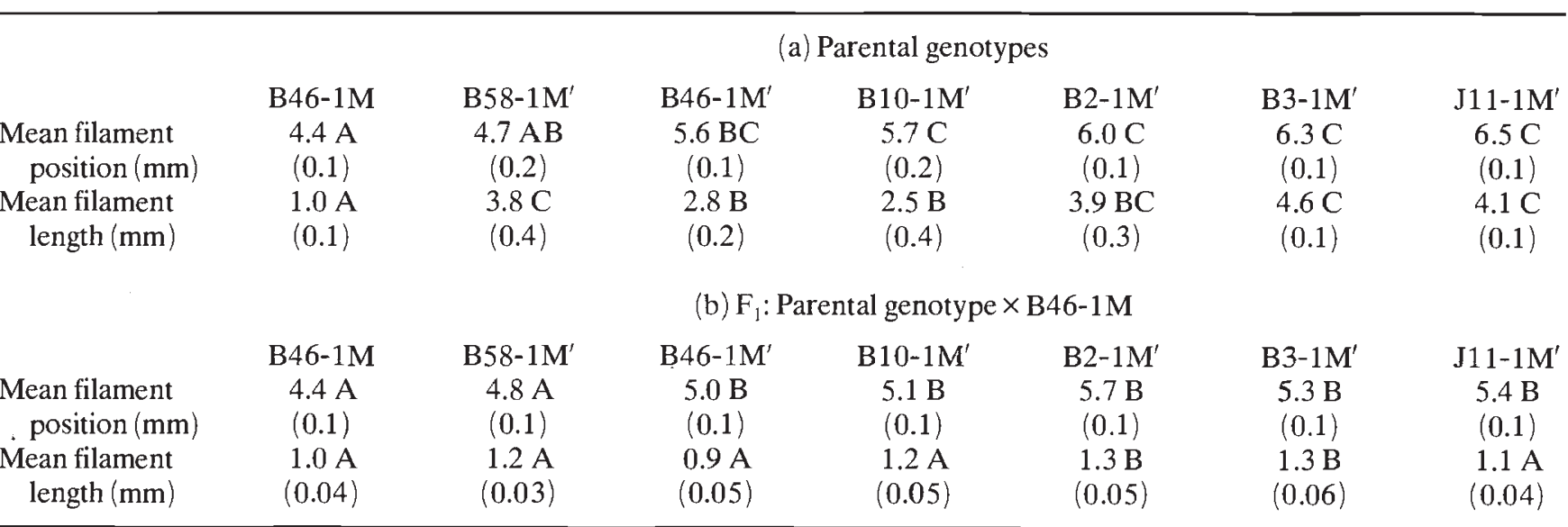

Table 3 Comparison of filament length and stigma-anther separation of developmentally homologous short-level stamens in mid- and long-styled morphs segregating from genotypes of Eichhornia paniculata heterozygous $(M m)$ at the $M$ locus; two S.E.s are in parentheses

\begin{tabular}{|c|c|c|c|c|c|c|}
\hline Parent & $\begin{array}{l}\text { Mid-styled morph } \\
\text { filament } \\
\text { length }(\mathrm{mm})\end{array}$ & $\begin{array}{l}\text { Long-styled morph } \\
\text { filament } \\
\text { length }(\mathrm{mm})\end{array}$ & $t$-value & $\begin{array}{l}\text { Mid-styled morph } \\
\text { stigma-anther } \\
\text { separation } \\
(\mathrm{mm})\end{array}$ & $\begin{array}{l}\text { Long-styled morph } \\
\text { stigma-anther } \\
\text { separation } \\
(\mathrm{mm})\end{array}$ & $t$-value \\
\hline B46-1M' & $2.8(0.4)$ & $1.2(0.4)$ & $3.785^{* * *}$ & $0.8(0.4)$ & $2.1(1.1)$ & $2.599^{*}$ \\
\hline B46-2M' & $3.3(0.1)$ & $2.4(0.4)$ & $5.558^{* * * * *}$ & $0.6(0.4)$ & $1.8(0.4)$ & $2.790^{*}$ \\
\hline B58-1 $\mathbf{M}^{\prime}$ & $3.8(0.8)$ & $1.8(0.4)$ & $3.150^{* *}$ & $1.2(0.8)$ & $4.5(0.6)$ & $4.519^{* * *}$ \\
\hline B58-2M' & $4.5(0.5)$ & $2.2(0.2)$ & $5.366^{* * *}$ & $0.9(0.6)$ & $4.8(0.6)$ & $7.266^{* * *}$ \\
\hline $\mathrm{B} 10-1 \mathbf{M}^{\prime}$ & $2.5(0.6)$ & $1.4(0.1)$ & $2.303^{* *}$ & $1.5(0.6)$ & $4.0(0.6)$ & $4.392^{* * * *}$ \\
\hline
\end{tabular}

$* P<0.05, * * P<0.01,{ }^{* * *} P<0.001$. 


\section{Variation in the expression of stamen modification}

Selfed progeny of $\mathrm{M}$ plants displayed several different patterns of stamen variation. The unmodified genotype B46-1M produced self progeny with short filament lengths that exhibited a low coefficient of variation (Fig. 2, c.v. $=12.0$ ). In contrast, self progeny of modified $\mathrm{M}$ genotypes, B46-1 $\mathrm{M}^{\prime}, \mathrm{B} 58-1 \mathrm{M}^{\prime}$ and $\mathrm{B} 58-2 \mathrm{M}^{\prime}$, had significantly longer filament lengths and displayed greater variation, (Fig. 2, c.v. $=36.8,47.2$ and 27.1, respectively). Self progeny of genotypes B46-2M', B3$1 \mathrm{M}^{\prime}, \mathrm{B} 2-1 \mathrm{M}^{\prime}$ and $\mathrm{J} 11-1 \mathrm{M}^{\prime}$ also had significantly longer filament lengths but exhibited a lower c.v. $(8.7,19.2$, 12.6 and 13.5 , respectively). Finally, the self progeny of $\mathrm{B} 10-1 \mathrm{M}^{\prime}$ fell into two discrete and non-overlapping classes with either short- or long-filament lengths.

Table 4 presents the dominance coefficients for filament position and filament length for crosses of modified genotypes with unmodified B46-1M. The two filament characters exhibited contrasting patterns of inheritance. No dominance was observed for filament position. The higher $F_{1}$ value for the cross $B 46-$ $1 \mathrm{M} \times \mathrm{B} 58-1 \mathrm{M}^{\prime}$ should not be taken as evidence for dominance since there was little difference between the two parents (Table 2a). However, filament length for all $F_{1}$ plants differed significantly from the midparent value, indicating near complete dominance for short filament length. In two cases the filament lengths of short-level stamens in $F_{1}$ plants were significantly different from the equivalent stamens of self progeny of the unmodified genotype B46-1M (Scheffé's contrasts, $P<0.05$, Table $2 \mathrm{~b}$ ). In the two exceptions the $F_{1}$ progeny closely resembled their unmodified parent (Table 2b, Fig. 3).

\section{Regional differentiation in genetic basis of stamen modification}

$F_{1}$ progeny of crosses among the modified genotypes can be categorized into one of four classes, corre-
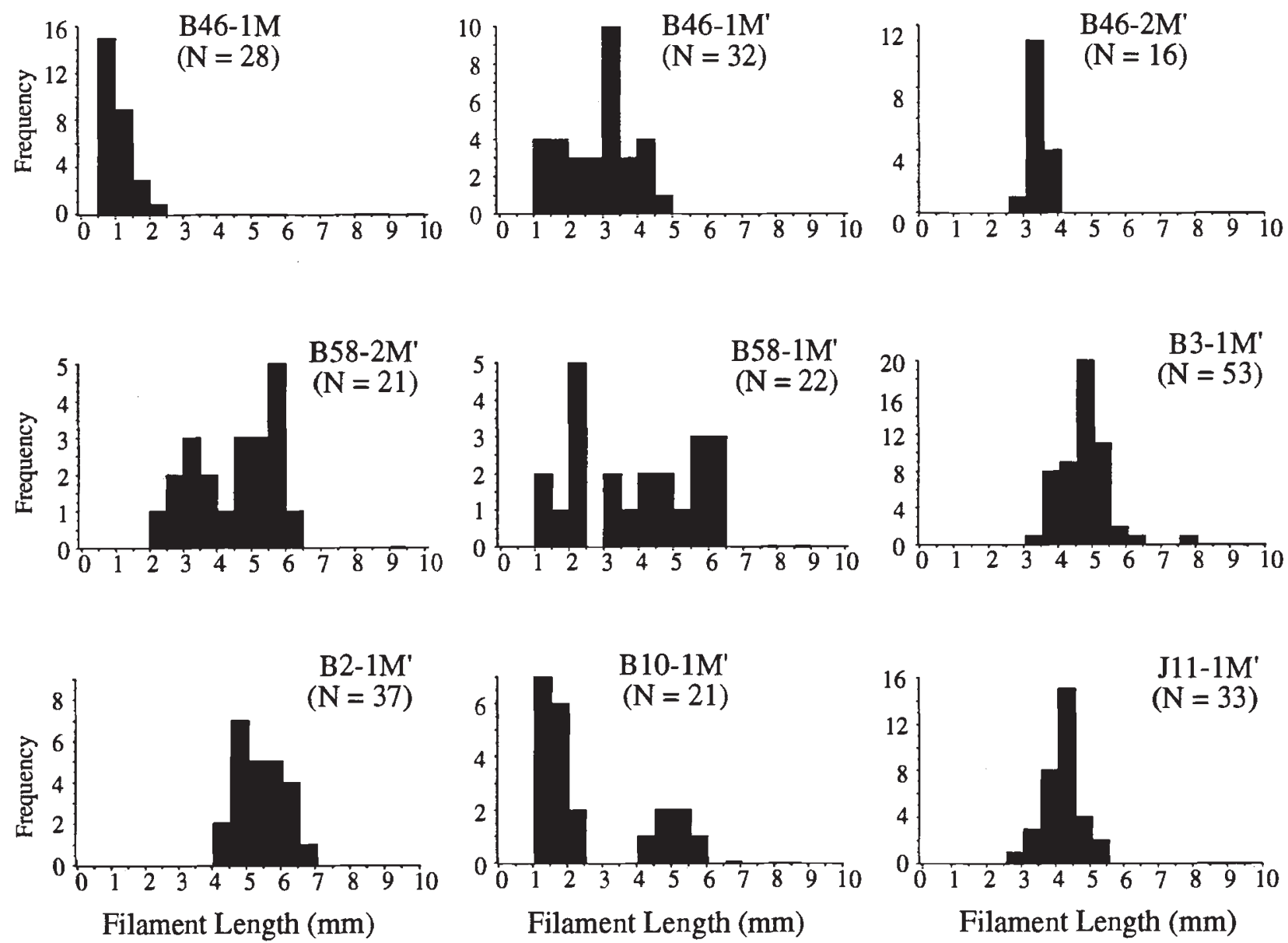

Fig. 2 Phenotypic distributions for filament length of selfed progeny of nine genotypes (one unmodified and eight modified) from six populations of Eichhornia paniculata in Brazil and Jamaica. 
sponding to crosses (1) within populations, (2) among populations within the same region (southern region of N. E. Brazil), (3) among populations in different regions (crosses between populations from the northern and southern portion of the range of E. paniculata in N.E. Brazil), and (4) between Jamaica and Brazil. Crosses among modified genotypes within populations B46

Table 4 Degree of dominance $(h)$ for the attachment position and length of the modifiable stamen in crosses between modified genotypes and unmodified B $46-1 \mathrm{M}$ of Eichhornia paniculata ( $h=0.50$, no dominance; $h=0.00$, wild type, unmodified mid dominant; $h=1.00$, modified mid dominant)

\begin{tabular}{ccc}
\hline Cross & Filament position & Filament length \\
\hline $\mathrm{B} 46-1 \mathrm{M} \times \mathrm{B} 58-1 \mathrm{M}^{\prime}$ & 1.33 & $0.07^{*}$ \\
$\mathrm{~B} 46-1 \mathrm{M} \times \mathrm{B} 46-1 \mathrm{M}^{\prime}$ & 0.50 & $-0.05^{*}$ \\
$\mathrm{~B} 46-1 \mathrm{M} \times \mathrm{B} 10-1 \mathrm{M}^{\prime}$ & 0.54 & $0.13^{*}$ \\
$\mathrm{~B} 46-1 \mathrm{M} \times \mathrm{B} 2-1 \mathrm{M}^{\prime}$ & 0.68 & $0.12^{*}$ \\
$\mathrm{~B} 46-1 \mathrm{M} \times \mathrm{B} 3-1 \mathrm{M}^{\prime}$ & 0.47 & $0.08^{*}$ \\
$\mathrm{~B} 46-1 \mathrm{M} \times \mathrm{J} 11-1 \mathrm{M}^{\prime}$ & 0.48 & $0.03^{*}$ \\
\hline
\end{tabular}

*Significant departure from mid-parent values $(P<0.005, t$ test). and B58 resulted in progeny which resembled the self progeny of either parent with respect to filament length (Table 5). Progeny derived from crossing modified mid-styled plants from within the southern region also resembled the self progeny of their parents, i.e. virtually all were modified (Table 6, Fig. 4). Crosses involving the modified $M$ from population B10 resulted in a segregation of modified and unmodified individuals and, consequently, a bimodal distribution of filament length (Fig. 4). In contrast to these results, crosses among modified mid-styled plants between the two regions of N.E. Brazil resulted in the recovery of plants with uniformly unmodified filament lengths (Fig. 5 and Table 6 , c.f. the first column of Table 6 with the following five columns).

The most complex distributions of stamen modification were observed in crosses of the Brazilian modified $M$ plants with the Jamaican genotype. Four patterns were evident: (1) recovery of mostly unmodified phenotypes but with a significantly long right-tailed distribution of modified individuals (Fig. $6, \mathrm{~J} \times \mathrm{B} 46-1 \mathrm{M}^{\prime}$, skewness $=1.472$, two S.E.s $=0.590),(2)$ mostly modified individuals, but with a significantly long left-tailed distribution of unmodified individuals (Fig. $6, \mathrm{~J} \times \mathrm{B} 58$ $1 \mathrm{M}^{\prime}$ and $\mathrm{J} \times \mathrm{B} 3-1 \mathrm{M}^{\prime}$, skewness $=-1.192,-1.640$, two S.E.s $=0.700,0.667$, respectively), (3) a symmetri-
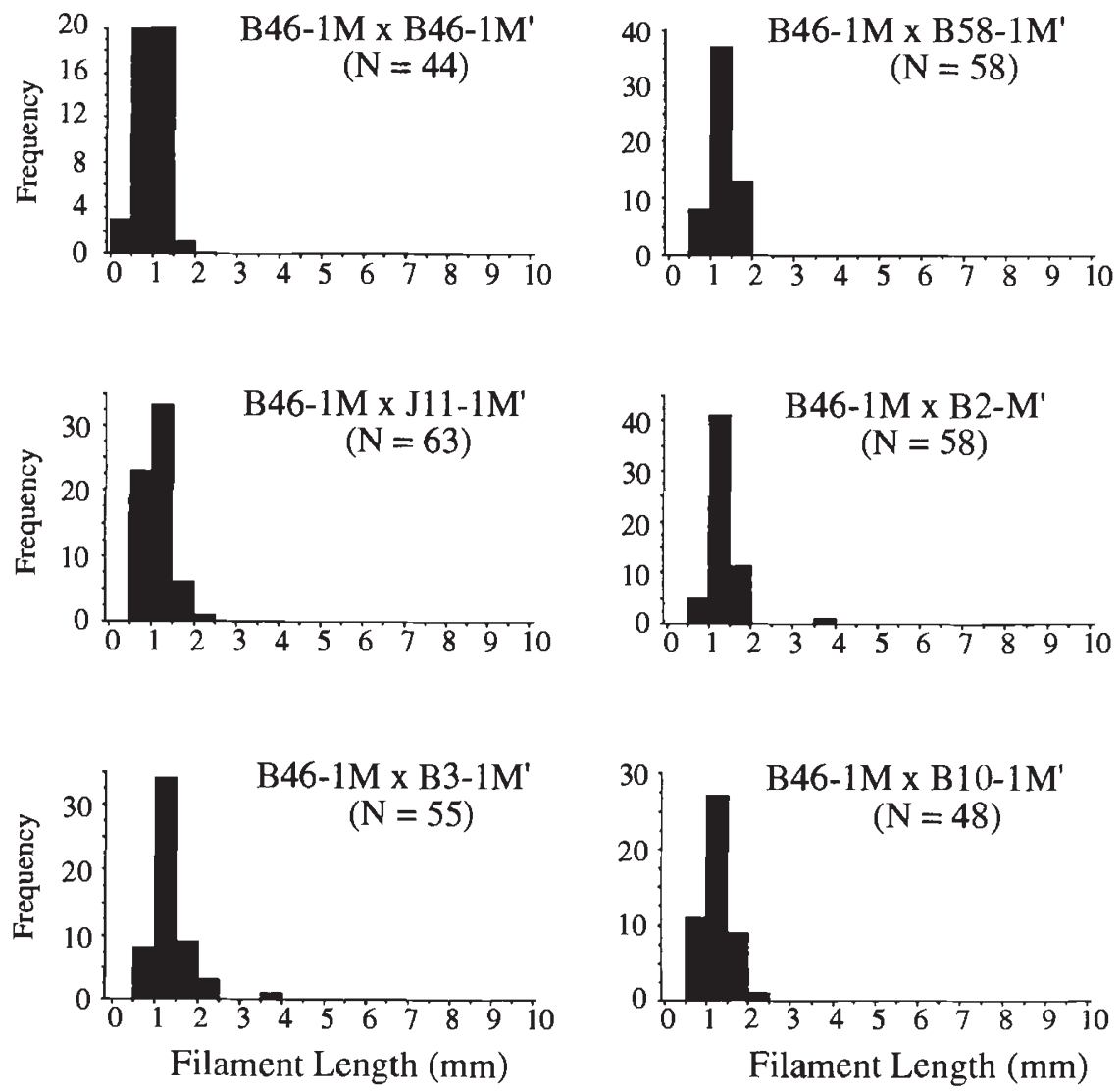

Fig. 3 Phenotypic distributions for filament length of $F_{1}$ progeny from crosses between unmodified B46-1M and six modified genotypes. 
Table 5 Mean filament length $(\mathrm{mm})$ of modifiable stamens in self and $F_{1}$ progeny from crosses between modified and unmodified genotypes from within populations B-46 and B-58 of Eichhornia paniculata; S.E.s are in parentheses

\begin{tabular}{|c|c|c|c|c|c|}
\hline & B46-1 $\mathrm{M}^{\prime}$ & $\mathrm{B} 46-2 \mathrm{M}^{\prime}$ & & B58-1M' & B58-2M' \\
\hline B46-1 $\mathrm{M}^{\prime}$ & $2.8(0.2)$ & $3.2(0.1)$ & B58-1 $M^{\prime}$ & $3.8(0.4)$ & $4.4(0.2)$ \\
\hline B46-2M' & & $3.3(0.1)$ & B58-2M' & & $4.5(0.3)$ \\
\hline
\end{tabular}

Table 6 Mean filament length $(\mathrm{mm})$ of the modified stamens in all pairwise crosses between selfing variants of Eichhornia paniculata; means followed by different letters in the same row are significantly different (Scheffé's contrasts, $P<0.05$ ); one S.E. in parentheses

\begin{tabular}{|c|c|c|c|c|c|c|}
\hline & \multirow{2}{*}{$\begin{array}{l}\text { Northern } \\
\text { N.E. } \\
\text { Brazil } \\
\text { B46-1 M' }^{\prime}\end{array}$} & \multicolumn{4}{|c|}{ Southern N.E. Brazil } & \multirow{2}{*}{$\frac{\text { Jamaica }}{\mathrm{J} 11-1 \mathbf{M}^{\prime}}$} \\
\hline & & B58-1 $\mathrm{M}^{\prime}$ & $\mathrm{B} 10-1 \mathrm{M}^{\prime}$ & B2-1 $M^{\prime}$ & B3-1 $\mathrm{M}^{\prime}$ & \\
\hline B46-1 $\mathrm{M}^{\prime}$ & $\begin{array}{l}2.9 \mathrm{C} \\
(0.19)\end{array}$ & $\begin{array}{c}1.4 \mathrm{AB} \\
(0.03)\end{array}$ & $\begin{array}{c}1.3 \mathrm{AB} \\
(0.06)\end{array}$ & $\begin{array}{c}1.5 \mathrm{~B} \\
(0.07)\end{array}$ & $\begin{array}{l}1.3 \mathrm{AB} \\
(0.04)\end{array}$ & $\begin{array}{c}1.6 \mathrm{~B} \\
(0.12)\end{array}$ \\
\hline B58-1 $\mathrm{M}^{\prime}$ & $\begin{array}{l}1.4 \mathrm{~A} \\
(0.03)\end{array}$ & $\begin{array}{c}3.8 \mathrm{BC} \\
(0.38)\end{array}$ & $\begin{array}{l}3.4 \mathrm{~B} \\
(0.32)\end{array}$ & $\begin{array}{l}4.6 \mathrm{C} \\
(0.15)\end{array}$ & $\begin{array}{c}4.3 \mathrm{BC} \\
(0.19)\end{array}$ & $\begin{array}{c}4.2 \mathrm{BC} \\
(0.17)\end{array}$ \\
\hline $\mathrm{B} 10-1 \mathbf{M}^{\prime}$ & $\begin{array}{r}1.3 \mathrm{~A} \\
(0.06)\end{array}$ & $\begin{array}{c}3.5 \mathrm{C} \\
(0.32)\end{array}$ & $\begin{array}{c}2.5 \mathrm{~B} \\
(0.35)\end{array}$ & $\begin{array}{l}3.4 \mathrm{C} \\
(0.26)\end{array}$ & $\begin{array}{c}3.0 \mathrm{BC} \\
(0.22)\end{array}$ & $\begin{array}{l}3.4 \mathrm{C} \\
(0.20)\end{array}$ \\
\hline $\mathrm{B} 2-1 \mathrm{M}^{\prime}$ & $\begin{array}{c}1.5 \mathrm{~A} \\
(0.07)\end{array}$ & $\begin{array}{l}4.6 \mathrm{C} \\
(0.15)\end{array}$ & $\begin{array}{c}3.5 \mathrm{~B} \\
(0.26)\end{array}$ & $\begin{array}{c}3.9 \mathrm{BC} \\
(0.34)\end{array}$ & $\begin{array}{c}5.1 \mathrm{C} \\
\langle 0.10\rangle\end{array}$ & $\begin{array}{c}4.4 \mathrm{C} \\
(0.08)\end{array}$ \\
\hline B3-1 $\mathbf{M}^{\prime}$ & $\begin{array}{r}1.3 \mathrm{~A} \\
(0.04)\end{array}$ & $\begin{array}{c}4.3 \mathrm{CD} \\
(0.19)\end{array}$ & $\begin{array}{c}1.7 \mathrm{~B} \\
(0.22)\end{array}$ & $\begin{array}{l}5.1 \mathrm{D} \\
\langle 0.10\rangle\end{array}$ & $\begin{array}{c}4.6 \mathrm{CD} \\
(0.10)\end{array}$ & $\begin{array}{l}4.1 \mathrm{C} \\
(0.12)\end{array}$ \\
\hline $\mathrm{J} 11-1 \mathbf{M}^{\prime}$ & $\begin{array}{l}1.6 \mathrm{~A} \\
(0.12)\end{array}$ & $\begin{array}{l}4.2 \mathrm{C} \\
(0.17)\end{array}$ & $\begin{array}{c}3.4 \mathrm{~B} \\
(0.20)\end{array}$ & $\begin{array}{l}4.4 \mathrm{C} \\
(0.08)\end{array}$ & $\begin{array}{l}4.1 \mathrm{C} \\
(0.12)\end{array}$ & $\begin{array}{l}4.1 \mathrm{C} \\
(0.10)\end{array}$ \\
\hline
\end{tabular}

cal distribution of modified individuals (Fig. 6, $\mathrm{J} \times \mathrm{B} 2$ $1 \mathrm{M}^{\prime}$, skewness $=-0.357$, two S.E.s $\left.=0.612\right)$, and $(4)$ a bimodal distribution of both modified and unmodified individuals involving the cross with population B10 (Fig. 6).

\section{Discussion}

The evolution of predominant self-fertilization in $E$. paniculata mainly involves the spread and fixation of self-pollinating variants of the mid-styled morph. The variants are characterized by modified short-level stamens, are scattered throughout the Brazilian range of the species, and also predominate on the island of Jamaica. The primary objective of our study was to investigate whether the genetic basis of stamen modification in these variants differed among populations from contrasting parts of the native range. This was achieved by crossing genotypes from two different regions of N.E. Brazil and from Jamaica.
While our inheritance studies only involved the use of first generation crosses, the results provided clear evidence that the genetic basis of stamen modification in the $\mathrm{M}$ morph differs between the regions sampled in Brazil. Crosses among modified genotypes from the southern portion of the N.E. Brazilian range resulted in offspring that were largely modified with respect to stamen position. This phenotype displays a high degree of autofertility under glasshouse conditions and exhibits a high selfing rate under field conditions (e.g. Glover \& Barrett, 1986; Barrett et al., 1989; Barrett \& Husband, 1990). In contrast, crosses between genotypes from southern populations and a modified genotype from the northern part of the Brazilian range resulted in unmodified mid-styled plants. To our knowledge this is the first report of the artificial synthesis of an 'outcrossing phenotype' from a cross between two 'selfing' phenotypes. This probably occurred because of complementary gene action involving the fixation of different recessive modifier genes in the two regions. However, further $\mathrm{F}_{2}$ and backcross genera- 

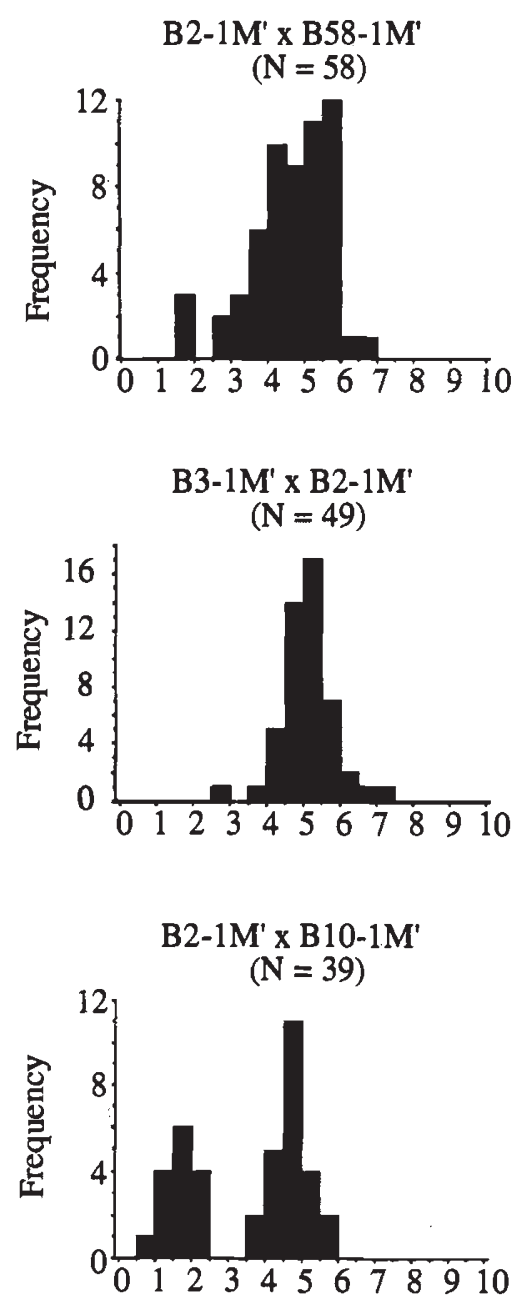

Filament Length (mm)
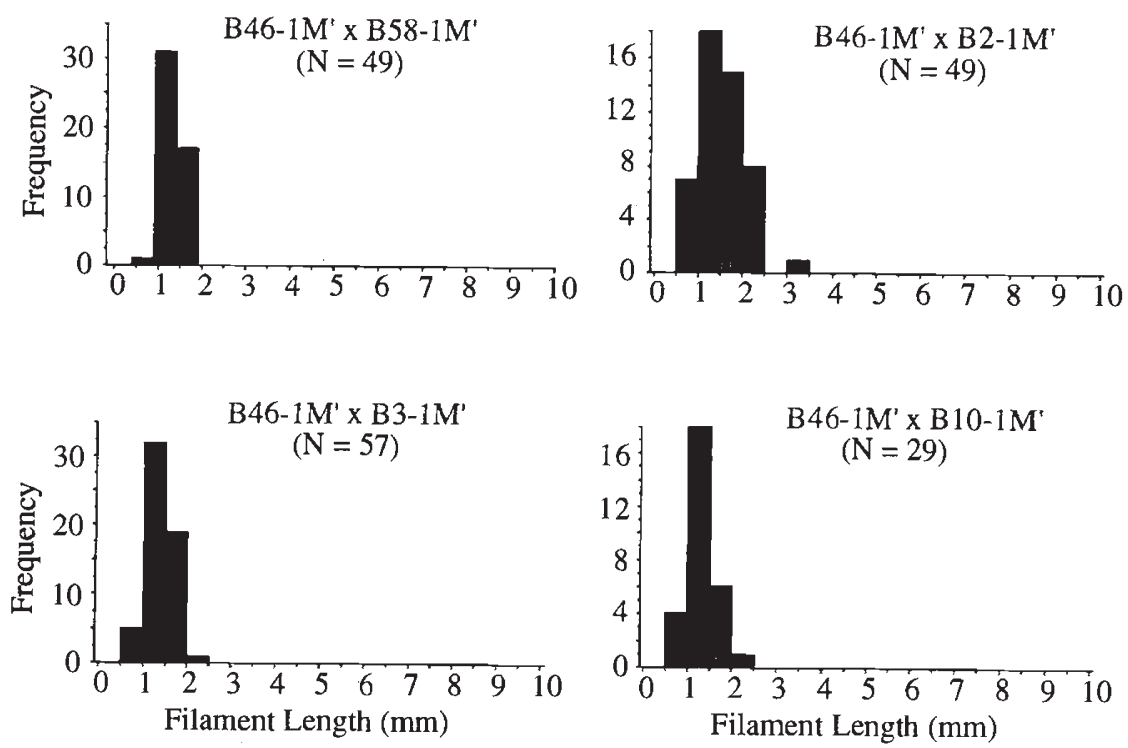

Fig. 4 Phenotypic distributions for filament length of $F_{1}$ progeny from crosses among the modified genotypes from the group of populations from the southern portion of the N.E. Brazilian range.
Fig. 5 Phenotypic distributions for filament length of $F_{1}$ progeny from crosses between the northern modified genotype, B46-1 $\mathrm{M}^{\prime}$, and modified genotypes from the southern portion of the N.E. Brazilian range. 
Fig. 6 Phenotypic distributions for filament length of $F_{1}$ progeny of Eichhornia paniculata from crosses between the modified Jamaican genotype, J11-1M', and modified individuals from Brazil.
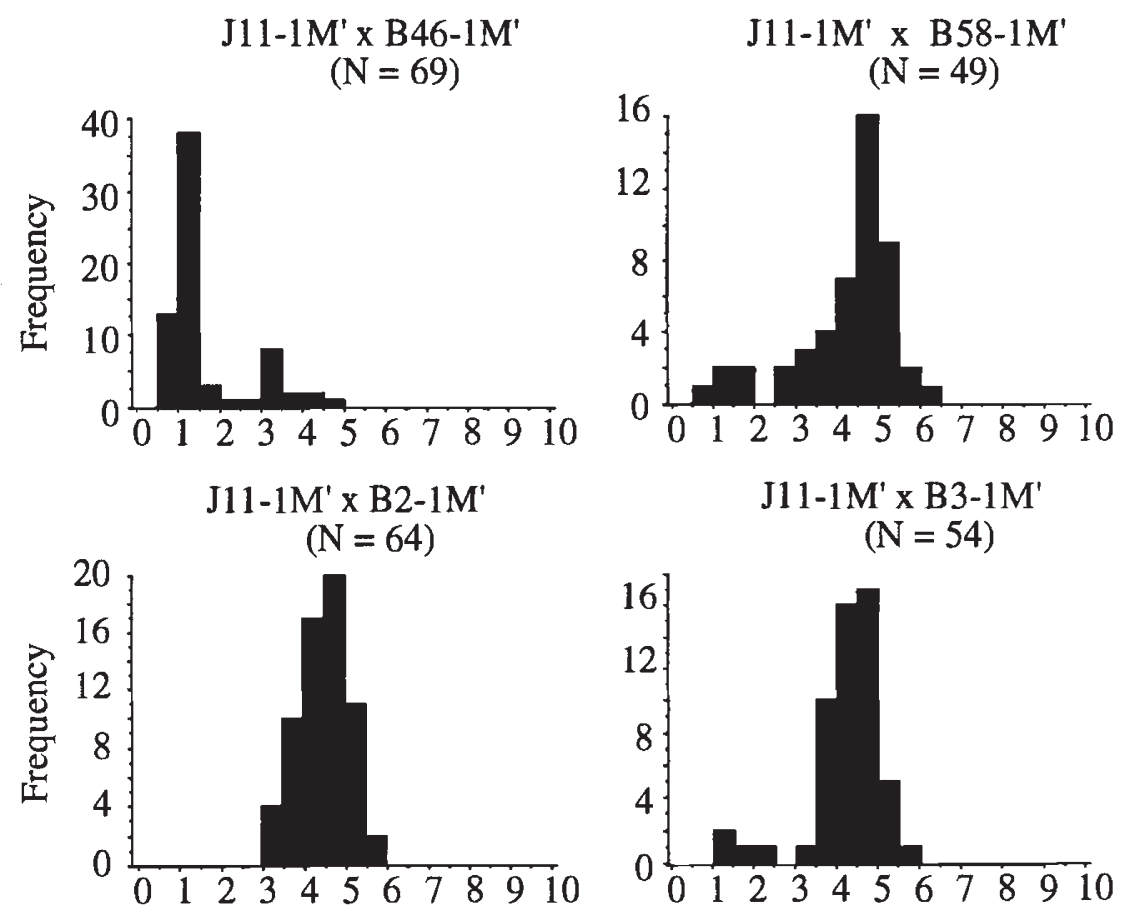

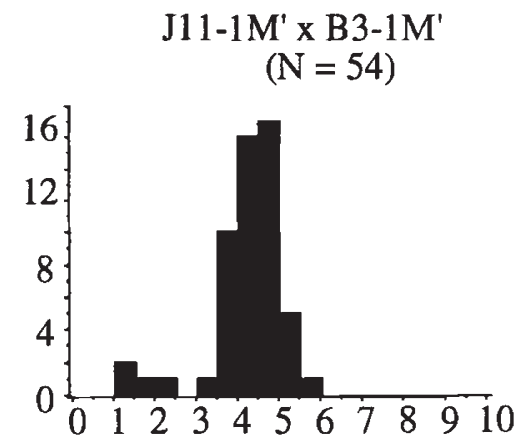

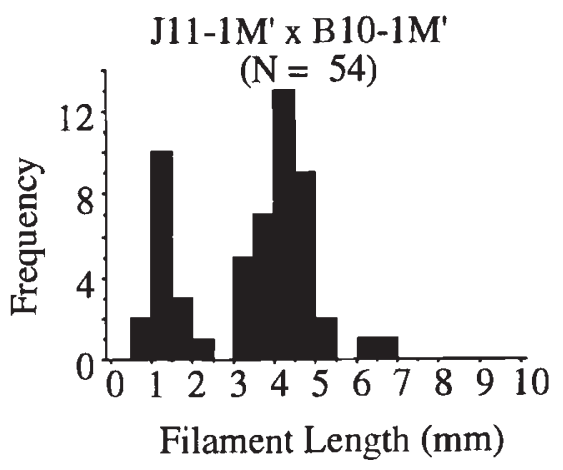

tions are required to establish the number of genes involved in stamen modification and to confirm the nature of gene action in modified genotypes.

The finding that different genetic factors modify short-level stamens in the mid-styled morph of E. paniculata is consistent with the hypothesis that self-fertilization may have originated independently in different parts of the Brazilian range of the species. Population studies of isozyme variation, the distribution of style morphs and the morphological characteristics of selfing variants by Husband and Barrett (1993) also support the multiple origin hypothesis. Analyses of genetic distance and the distribution of rare alleles in an isozyme survey of 44 populations in N.E. Brazil indicated that selfing variants may have originated on at least three separate occasions in association with the loss of style morphs from populations. Of particular relevance to the present study was the finding that the northern population B46 was electrophoretically distinct from all southern populations containing selfpollinating variants. The presence of diagnostic alleles in this population that were shared by nearby trimorphic populations, but absent from all southern populations, was used by Husband and Barrett as evidence that population B46 was historically distinct from southern populations with self-pollinating variants and represented a separate origin for selffertilization in the species.

Elsewhere it has been proposed that frequent bottlenecks and periods of small population size can readily destabilize the tristylous polymorphism in E. paniculata initiating conditions that favour the spread of selfpollinating variants (Barrett et al., 1989). The relatively minor phenotypic changes required to bring about selfpollination in $E$. paniculata, and the possibility that such changes are under the control of a small number of recessive genes, may mean that selfing is considerably easier to achieve than in many non-heterostylous 
taxa where floral traits more commonly show quantitative variation. Barrett \& Shore (1987) documented three separate origins for the breakdown of distyly to homostyly in Turnera ulmifolia at different margins of the neotropical range of the species. Unlike E. paniculata, however, selfing in this species has arisen by recombination in the supergene governing the distylous polymorphism (Shore \& Barrett, 1985), rather than by the action of recessive modifier genes.

Our study focused on self-pollinating variants of the $\mathrm{M}$ morph with modified short-level stamens. This is because these variants are the most common selfing phenotype found in natural populations of E. paniculata occurring in many dimorphic and monomorphic populations of the species (Husband \& Barrett, 1993). However, the facility to evolve a selfing phenotype is not restricted to the $\mathrm{M}$ morph. A single isolated population of E. paniculata composed exclusively of selfpollinating variants of the $\mathrm{L}$ morph has been reported from Nicaragua (Barrett, 1988). Plants in this population have very small flowers and mid-level stamens adjacent to stigmas of $\mathrm{L}$ styles. Crosses between these phenotypes and unmodified $\mathrm{L}$ and $\mathrm{M}$ plants confirm that they are modified variants of the $\mathrm{L}$ morph (S. C. H. Barrett, unpublished data). Whereas floral modifications governing selfing in the $\mathrm{M}$ morph largely involve discrete phenotypic changes in stamen length, suggesting a small number of major genes, in the modified $\mathrm{L}$ morph from Nicaragua floral variation is continuous, indicating that mating-system modification is more likely to be polygenically controlled. The occurrence of these different floral variants provides further evidence for multiple origins of self-fertilization in E. paniculata and also suggests that different genetic factors are involved with floral modification.

In our study, plants of the L morph segregating from controlled pollinations of selfing $\mathrm{M}$ variants heterozygous at the $M$ locus $(M m)$ displayed no floral modifications to their short-level stamens (Table 3). This indicates that the genes modifying short-level stamens in the $\mathrm{M}$ morph are only expressed when present in the $M$ phenotype. Field observations from dimorphic populations composed of $\mathrm{L}$ and $\mathrm{M}$ plants support this view. For example, in Jamaica where selfing variants of the $\mathrm{M}$ morph predominate on the island, the less common L morph exhibits an unmodified phenotype although in dimorphic populations the two morphs regularly interbreed. These observations indicate that the genetic and developmental mechanisms governing modifications to floral organ position in the $\mathrm{L}$ and $\mathrm{M}$ morphs are highly morph-specific. A similar conclusion was reached by Richards \& Barrett (1987) in their study of the developmental basis of tristyly in the related Pontederia cordata. Allometric analysis of the relative growth of stamens indicated that the developmental processes resulting in the complementary arrangement of organs in different morphs was specific to the morph and not to whether stamens were long, mid or short in position.

We did not observe any correlated changes between stamen modification in the $\mathrm{M}$ morph and other floral characters including the pistil, perianth and remaining stamens of both the short and long-level anther levels. This finding is consistent with a multivariate study of floral variation in self-pollinating variants of the $M$ morph by Seburn et al. (1990). These authors also found no correlated changes in floral traits associated with short-level stamen modification. These observations suggest a high degree of specificity of gene action affecting organ development and do not provide strong support for the suggestion that major shifts in plant morphology are inevitably associated with negative pleiotropic consequences to fitness (see Coyne \& Lande, 1985; but see also Gottlieb, 1984, and Orr \& Coyne, 1992). Presumably, the absence of correlated effects associated with stamen modification reflects the fact that filament elongation of the modified stamen occurs late in development, only being manifest within $24 \mathrm{~h}$ prior to anthesis (see Fig. 41 in Richards \& Barrett, 1992). However, it should be noted that the assessment of the direct and indirect fitness effects of novel floral morphologies, particularly in animal-pollinated plants, should be quantified under field conditions.

Since there are no apparent changes to floral morphology associated with stamen elongation in the $M$ morph it seems unlikely that when the variant phenotype initially arises in populations it would be discriminated against by pollinators. However, modified stamens are likely to have profound effects on the mating system of populations. Since long-level anthers are unaffected by short-level stamen elongation in the $\mathrm{M}$ morph, their ability to transfer pollen to stigmas of long-styled plants is unlikely to be compromised. Hence, in dimorphic populations pollen discounting (Holsinger et al., 1984), or the reduction in male fertility associated with selfing (Fisher, 1941), is probably not associated with filament length elongation in the $\mathrm{M}$ morph. Indeed, experimental studies using genetic markers and the manipulation of population morph structure in E. paniculata indicate that in the absence of the $S$ morph, self-pollinating $M$ variants experience a male transmission advantage over unmodified $\mathrm{M}$ plants as a result of their higher outcross pollen success (Kohn \& Barrett, 1994). This appears to arise because the close proximity of mid-level stigmas and elongated short-level anthers improve pollen export to both modified and unmodified $\mathrm{M}$ plants, since pollen is 
placed on a location of the pollinator which increases its transfer efficiency. The influence of changes in anther position on pollen transfer efficiency and male reproductive success in animal-pollinated plants is discussed more fully by Campbell (1989) and Harder and Barrett (1993).

The uniform expression of dominance in the unmodified $\mathrm{M}$ plants over elongation of filament length in self-pollinating variants indicates that the evolution of self-fertilization in $E$. paniculata results, in part, from the selective fixation of recessive alleles modifying filament length. The introduction of a selectively advantageous recessive allele into a large population has been shown to have a high probability of extinction (i.e. 'Haldane's Sieve', Haldane, 1924, 1927; Turner, 1981). However, the increased selfing associated with filament length elongation enhances the probability of the spread and fixation of favourable recessive alleles, since loci which increase selfing will favour recovery of homozygotes for the recessive alleles (Charlesworth, 1992). This process is likely to be further augmented in $E$. paniculata because of the species' colonizing lifehistory. Periodic population bottlenecks and small effective population sizes give rise to biparental inbreeding in many populations (Barrett \& Husband, 1990; Husband \& Barrett, 1992). This provides further opportunities for the exposure and selection of favourable recessive alleles made homozygous through inbreeding.

Spread of the recessive modifier genes in populations of $E$. paniculata could potentially generate inbreeding depression due to increased rates of selffertilization. Two factors, however, may help to counteract the reduced vigour of progeny following selfing and hence promote the spread of genes modifying rates of self-fertilization. First, modifier genes which increase the selfing rate are likely to be favoured during periods of low density or following episodes of colonization because they result in reproductive assurance (Baker, 1955). Second, experimental studies of $E$. paniculata populations containing modified variants indicate that inbreeding depression is either very weak or absent (Toppings, 1989; Barrett and Charlesworth, 1991). Population bottlenecks in this annual colonizing species of ephemeral aquatic habitats may purge populations of sufficient amounts of genetic load to favour the spread of recessive modifiers that increase selfing rates (Lande \& Schemske, 1985; Barrett et al., 1989). The alternative possibility that a reduction in genetic load may have followed the spread of the modifier genes cannot, however, be ruled out.

Although our data must be considered preliminary, genetic modifications to filament length in the $M$ morph follow a complex pattern of inheritance depending on the populations being crossed. Unmodified $\mathrm{M}$ progeny were recovered upon selfing modified $\mathrm{M}$ parents from populations B10, B46 and B58, despite clear evidence for the recessive nature of stamen modification in all population crosses. It has been previously observed that crosses between modified $M$ plants from Jamaica with unmodified $M$ individuals from Brazil resulted in the recovery of both parental types in the $F_{2}$ generation, yet $F_{2}$ individuals do not breed completely true when selfed (S. C. H. Barrett, unpublished data). These observations suggest that stamen modification in the $\mathrm{M}$ morph involves several recessive genes but that genetic background effects govern their expression, particularly in interpopulation crosses. For example, when $\mathrm{J}_{11} 1-1 \mathrm{M}^{\prime}$ was crossed to the northern Brazilian genotype $\mathrm{B} 46-1 \mathrm{M}^{\prime}$, mostly unmodified individuals were recovered but with a long right tail of modified individuals (Fig. 6). In contrast, a long left tail of unmodified individuals was

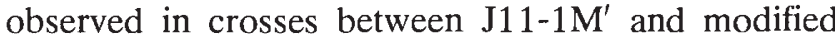
individuals from the southern populations B58 and B3. The cross between $\mathrm{J} 11-1 \mathrm{M}^{\prime}$ and $\mathrm{B} 3-1 \mathrm{M}^{\prime}$ was particularly informative since $\mathrm{B} 3-1 \mathrm{M}^{\prime}$ bred true when selfed. These skewed distributions suggest that genes affecting filament length elongation are expressed differently depending on the particular genetic background they are in. In addition, the contrasting distributions obtained for northern and southern populations from N.E. Brazil, when crossed to the Jamaican genotype, are consistent with the interpretation that different recessive modifiers are responsible for stamen modification in the two regions.

The role of modifiers and background effects in the expression of traits has often been documented in association with dominance, e.g. the genetic basis of the mimicry complex in the African swallow tail butterfly Papilio dardanus (Clarke \& Sheppard, 1960; Clarke et al., 1968) or of flower colour variants in Gossypium hirsutum and G. barbadense (Harland, 1936). In these instances discrete phenotypes often break down into a series of continuous character states when crosses are made between races or species fixed for different modifier alleles. Stamen modification in the M morph of $E$. paniculata may have an analogous genetic basis in that consistent expression of loci responsible for filament length elongation is influenced by genetic background. The presence of genetic background effects, or epistasis ( sensu Wright, 1931), has been inferred by the loss of a response to selection when crossing selected lines. In natural populations multiple peak epistasis has been demonstrated in crosses between different populations of the blind cave fish Anuptichthys antrobius resulting in $F_{1}$ progeny with larger retina size (Wilkens, 
1971) and by the breakdown of pesticide resistance (King, 1955; McKenzie et al., 1982). Other examples are reviewed in Cohan (1984).

The evolutionary breakdown of tristyly in E. paniculata is initiated by the spread of recessive modifier allele $(\mathrm{s})$ causing elongation of a single short-level stamen in the $\mathrm{M}$ morph. Our data indicate that the gene(s) have little influence on other aspects of floral morphology. Further accumulation of modifier loci, however, gives rise to small-flowered highly selfing populations which undoubtedly differ from outcrossing populations at a large number of loci. Reduction of flower size, loss of nectar guides and the elongation of all three lower-level anthers in certain highly autogamous populations from Jamaica suggest that at least some of the populations in this region have experienced a longer period of selection for predominant self-fertilization. The importance of these evolutionary changes to floral morphology are that major shifts in the mating system are apparently precipitated by relatively minor alterations to the position of a single stamen.

\section{Acknowledgements}

Research funded by an operating grant from the Natural Sciences and Engineering Research Council of Canada to S. C. H. Barrett. Cathy Christiansen and M. Dudash made helpful comments on earlier versions of the manuscript.

\section{References}

BAKER, H. G. 1955. Self-compatibility and establishment after 'long-distance' dispersal. Evolution, 11, 449-460.

BAKER, H. G. 1959. The contribution of autecological and genecological studies to our knowledge of the past migrations of plants. Am. Nat., 93, 255-272.

BAKER, H. G. 1966. The evolution, functioning and breakdown of heteromorphic incompatibility systems. I. The Plumbaginaceae. Evolution, 20, 349-368.

BARRETT, S. C. H. 1979. The evolutionary breakdown of tristyly in Eichhornia crassipes (Mart.) Solms. (Water Hyacinth). Evolution, 33, 499-510.

BARRETT, S. C. H. 1985. Floral trimorphism and monomorphism in continental and island populations of Eichhornia paniculata (Spreng.) Solms. (Pontederiaceae). Biol. J. Linn. Soc., 25, 41-60.

BARRETT, S. C. H. 1988. Evolution of breeding systems in Eichhornia: a review. Ann. M. Bot. Gard., 75, 741-760.

BARRETT, s. C. H. 1989. Mating system evolution and speciation in heterostylous plants. In: Otte, D. and Endler, J. (eds.) Speciation and its Consequences, pp. 257-283. Sinauer Associates, Sunderland, MA.

BARRETT, S. C. H. 1992. Heterostylous genetic polymorphisms: Model systems for evolutionary analysis. In: Barrett, S. C. H. (ed.) Evolution and Function of Heterostyly. pp. 1-29. Springer-Verlag, Berlin.
BARRETT, S. C. H. AND CHARLESWORTH, D. 1991. Effects of a change in the level of inbreeding on the genetic load. Nature, 352, 522-524.

BARRETT, S. C. H. AND HARDER, L. D. 1992. Floral variation in Eichhornia paniculata (Spreng.) Solms. (Pontederiaceae). 2. Effects of development and environment on the formation of selfing flowers. J. Evol. Biol., 5, 83-107.

BARRETT, S. C. H. AND HUSBAND, B. C. 1990. Genetics of plant migration and colonization. In: Brown, A. H. D., Clegg, M. T., Kahler, A. L. and Weir, B. S. (eds) Plant Population Genetics, Breeding and Genetic Resources, pp. 254-277. Sinauer Associates, Sunderland, MA.

BARRETT, S. C. H. AND SHORE, J. 1987. Variation and evolution of breeding systems in the Turnera ulmifolia complex (Turneraceae). Evolution, 41, 340-354.

BARRETT, S. C. H., MORGAN, M. T. AND HUSBAND, B. C. 1989. The dissolution of a complex genetic polymorphism: The evolution of self-fertilization in tristylous Eichhornia paniculata (Pontederiaceae). Evolution, 43, 1398-1416.

BREESE, E. L. 1959. Selection for differing degrees of outbreeding in Nicotiana rustica. Ann. Bot., 23, 331-344.

BROWN, B. A. AND CLEGG, M. T. 1984. Influence of flower color polymorphism on genetic transmission in a natural population of the common morning glory, Ipomoea purpurea. Evolution, 38, 796-803.

CAMPBELL, D. R. 1989. Measurements of selection in a hermaphroditic plant: Variation in male and female pollination success. Evolution, 43, 318-334.

CAMPBELL, R. B. 1986. The interdependence of mating structure and inbreeding depression. J. Theor. Biol., 30 , $232-244$.

CHARLESWORTH, B. 1992. Evolutionary rates in partially selffertilizing species. Am. Nat., 140, 126-148.

CHARLESWORTH, D. 1979. The evolution and breakdown of tristyly. Evolution, 33, 486-498.

CHARLESWORTH, D. AND CHARLESWORTH, B. 1979. A model for the evolution of distyly. Am. Nat., 114, 467-498.

CHARLESWORTH, D. AND CHARLESWORTH, B. 1990. Inbreeding depression with heterozygote advantage and its effect on selection for modifiers changing the outcrossing rate. Evolution, 44, 870-888.

CLARKE, C. A. AND SHEPPARD, P. M. 1960. Supergenes and mimicry. Heredity, 14, 175-185.

CLARKE, C. A., SHEPPARD, P. M. AND THORNTON, 1. W. B. 1968. The genetics of the mimetic butterfly Papilio memnon L. Phil. Trans. R. Soc. Ser. B., 254, 5-89.

CLEGG, M. T. AND EPPERSON, B. K. 1988. Natural selection of flower color polymorphisms in morning glory populations. In: Gottlieb, L. D. and Jain, S. K. (eds) Plant Evolutionary Biology, pp. 255-273. Chapman and Hall, London.

COHAN, F. M. 1984. Can uniform selection retard random genetic divergence between isolated conspecific populations? Evolution, 38, 495-504.

COYNE, J. A. AND LANDE, R. 1985. The genetic basis of species differences in plants. Am. Nat., 126, 141-145.

Dowrick, V. P. J. 1956. Heterostyly and homostyly in Primula obconica. Heredity, 10, 219-236.

ENNOS, R. A. 1981. Quantitative studies of the mating system in two sympatric species of Ipomoea (Convolvulaceae). Genetica, 57, 93-98. 
ERNST, A. 1955. Self-fertility in monomorphic Primulas. Genetica, 27, 91-148.

FENSTER, C. B. AND RITLAND, K. 1994. The quantitative genetics of mating system divergence in the yellow monkeyflower species complex. Heredity, (in press).

FISHER, R. A. 1941. Average excess and average effect of a gene substitution. Ann. Eugen., 11, 53-63.

GLOVER, D. E. AND BARRETT, S. C. H. 1986. Variation in the mating system of Eichhornia paniculata (Spreng.) Solms. (Pontederiaceae). Evolution, 40, 1122-1131.

GOTTLIEB, L. D. 1984. Genetics and morphological evolution in plants. Am. Nat., 123, 681-709.

HALDANE, J. B. s. 1924. A mathematical theory of natural and artificial selection. Part I. Trans. Camb. Phil. Soc., 23, $19-41$.

HALDANE, J. B. S. 1927. A mathematical theory of natural and artificial selection. Part V. Selection and mutation. Proc. Camb. Phil. Soc., 23, 838-844.

HARDER, L. D. AND BARRETT, S. C. H. 1993. Pollen removal from tristylous Pontederia cordata: Effects of anther position and pollinator specialization. Ecology, 74, 1059-1072.

HARLAND, S. C. 1936. The genetical conception of the species. Biol. Rev., 11, 83-112.

HOLSINGER, K. E. 1992. Ecological models of plant mating systems and the evolutionary stability of mixed mating systems. In: Wyatt, R. (ed.) Ecology and Evolution of Plant Reproduction, pp. 169-191. Chapman and Hall, New York.

HOLSINGER, K. E., FELDMAN, M. W. AND CHRISTIANSEN, R. B. 1984. The evolution of self-fertilization in plants. A population genetic model. Am. Nat., 124, 446-453.

HOLTSFORD, T. P. AND ELLSTRAND, N. C. 1992. Genetic and environmental variation in floral traits affecting outcrossing rate in Clarkia tembloriensis (Onagraceae). Evolution, 46, 216-225.

HUSBAND, B. C. AND BARRETT, S. C. H. 1992. Effective population size and genetic drift in tristylous Eichhornia paniculata (Pontederiaceae). Evolution, 46, 1875-1890.

HUSBAND, B. C. AND BARRETT, S. C. H. 1993. Multiple origins of self-fertilization in tristylous Eichhornia paniculata (Pontederiaceae): inferences from style morph and isozyme variation. J. Evol. Biol., 6, 591-608.

JAIN, K. B. L., SCHALLER, C. W. AND JAIN, S. K. 1979. Genetic variation in the outcrossing rates in barley. Genetica, 50, 41-49.

KING, J. C. 1955. Evidence for the integration of the gene pool from studies of DDT resistance in Drosophila. Cold Spring Harbor Symp. Quant. Biol., 20, 311-317.

KOHN, J. R. AND BARRETT, S. C. H. 1994. Pollen discounting and the spread of a selfing variant in tristylous Eichhornia paniculata: Evidence from experimental populations. Evolution, (in press).

LANDE, R. AND SCHEMSKE, D. w. 1985. The evolution of selffertilization and inbreeding depression in plants. I. Genetic models. Evolution, 39, 24-40.

LATTA, R. AND RITLAND, K. 1993. Models for the evolution of selfing under alternative modes of inheritance. Heredity, 71, 1-10.

LEWIS, D. AND JONES, D. A. 1992. The genetics of heterostyly. In: Barrett, S. C. H. (ed.) Evolution and Function of Heterostyly, pp. 129-150. Springer-Verlag, Berlin.
MACNAIR, M. R. AND CUMBES, Q. J. 1989. The genetic architecture of interspecific variation in Mimulus. Genetics, 122, 211-222.

MARSHALL, D. F. AND ABBotT, R. J. 1982. Polymorphism for outcrossing frequency at the ray floret locus in Senecio vulgaris L. I. Evidence. Heredity, 48, 227-235.

MATHER, K. 1950. Genetic architecture of heterostyly in Primula sinensis. Evolution, 4, 340-352.

MCKENZIE, J. A., WHITTEN, M. J. AND ADENA, M. A. 1982. The effect of genetic background on the fitness of diazinon resistance genotypes of the Australian sheep blowfly, Lucilia cuprina. Heredity, 49, 1-9.

MOORE, D. M. AND LEWIS, H. 1965. The evolution of self-pollination in Clarkia xantiana. Evolution, 19, 104-114.

ORR, A. H. AND COYNE, J. A. 1992. The genetics of adaptations: A reassessment. Am. Nat., 140, 725-742.

RICHARDS, J. H. AND BARRETT, S. C. H. 1987. Development of tristyly in Pontederia cordata L. 1. Mature floral structure and patterns of relative growth of reproductive organs. Am. J. Bot., 74, 1831-1841.

RICHARDS, J. H. AND BARRETT, S. C. H. 1992. The development of heterostyly. In: Barrett, S. C. H. (ed.) Evolution and Function of Heterostyly, pp. 85-127. Springer-Verlag, Berlin.

RICK, C. M. 1947. A hair-suppressing gene that indirectly affects fruitfulness and the proportion of cross-pollination in the tomato. Genetics, 32, 101-102.

ROSS, M. D. AND ABBOTT, R. J. 1987. Fitness, sexual asymmetry, functional sex and selfing in Senecio vulgaris L. Evol. Trends Plants, 1, 21-28.

SCHOEN, D. J. 1982. The breeding system of Gilia achilleifolia: Variation in floral characteristics and outcrossing rate. Evolution, 36, 352-360.

SEBURN, C. N., DICKINSON, T. A. AND BARRETT, S. C. H. 1990. Floral variation in Eichhornia paniculata (Spreng.) Solms. (Pontederiaceae). 1. Instability of stamen position in genotypes from N.E. Brazil. J. Evol. Biol., 3, 103-123.

SHORE, J. S. AND BARRETT, S. C. H. 1985. Genetics of distyly and homostyly in the Turnera ulmifolia complex (Turneraceae). Heredity, 55, 167-174.

SHORE, J. S. AND BARRETT, S. C. H. 1990. Quantitative genetics of floral characters in homostylous Turnera ulmifolia var. angustifolia (Turneraceae). Heredity, 64, 105-112.

TOPPINGS, P. 1989. The Significance of Inbreeding Depression to the Evolution of Self-fertilization in Eichhornia paniculata (Spreng.) Solms. (Pontederiaceae). M. Sc. Thesis, University of Toronto.

TURNER, J. R. G. 1981. Adaptation and evolution in Heliconius: a defense of neo-Darwinism. Ann. Rev. Ecol. Syst., 12, 99-121.

VASEK, F. C. 1968. Outcrossing in natural populations. IV. A comparison of outcrossing estimation methods. In: Drake, E. T. (ed.) Evolution and Environment. Yale University Press, New Haven, CT.

WILKENS, H. 1971. Genetic interpretation of regressive evolutionary processes: studies on hybrid eyes of two astyanax cave populations. Evolution, 25, 530-540.

WRIGHT, s. 1931. Evolution in Mendelian populations. Genetics, 16, 97-159.

WRIGHT, s. 1968. Evolution and the Genetics of Populations. I. Genetic and Biometrical Foundations. The University of Chicago Press, Chicago. 